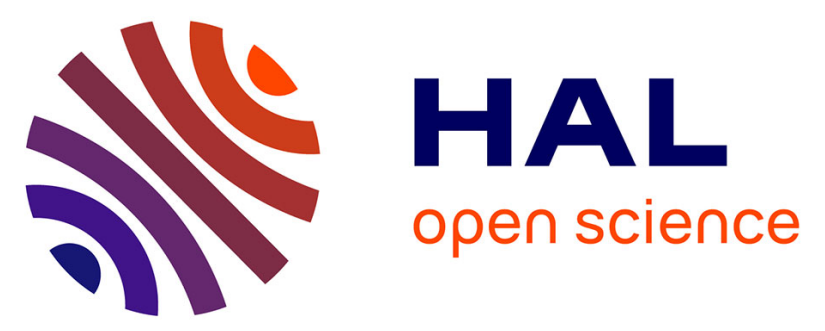

\title{
Comparative bioaccumulation of trace elements between Nautilus pompilius and N. macromphalus (Cephalopoda: Nautiloidea) from Vanuatu and New-Caledonia
}

Mathieu Pernice, Julien Boucher, Renata Boucher-Rodoni, Pascale Joannot, Paco Bustamante

\section{To cite this version:}

Mathieu Pernice, Julien Boucher, Renata Boucher-Rodoni, Pascale Joannot, Paco Bustamante. Comparative bioaccumulation of trace elements between Nautilus pompilius and N. macromphalus (Cephalopoda: Nautiloidea) from Vanuatu and New-Caledonia. Ecotoxicology and Environmental Safety, 2009, 72 (2), pp.365- 371. 10.1016/j.ecoenv.2008.04.019 . hal-00336127

\section{HAL Id: hal-00336127 https://hal.science/hal-00336127}

Submitted on 1 Nov 2008

HAL is a multi-disciplinary open access archive for the deposit and dissemination of scientific research documents, whether they are published or not. The documents may come from teaching and research institutions in France or abroad, or from public or private research centers.
L'archive ouverte pluridisciplinaire HAL, est destinée au dépôt et à la diffusion de documents scientifiques de niveau recherche, publiés ou non, émanant des établissements d'enseignement et de recherche français ou étrangers, des laboratoires publics ou privés. 
1 Comparative bioaccumulation of trace elements between Nautilus pompilius and $N$.

4 Running title: influence of the environment on bioaccumulation of trace elements in Nautilus 5

6 PERNICE Mathieu', BOUCHER Julien ${ }^{2}$, BOUCHER-RODONI Renata ${ }^{1}$, JOANNOT 7 Pascale $^{3}$, BUSTAMANTE Paco ${ }^{4 \#}$

${ }^{1}$ UMR 5178 Biologie des Organismes Marins et Ecosystèmes, DMPA, Muséum National 10 d'Histoire Naturelle, 55 rue Buffon, 75005 Paris, France.

112 Ecole Polytechnique Fédérale de Lausanne, LGCB-ISIC-SB-EPFL1015 Lausanne, 12 Switzerland.

$13{ }^{3}$ Direction des Collections, Muséum National d'Histoire Naturelle, Cour Fagon, 57 rue 14 Cuvier, 75005 Paris, France.

${ }^{4}$ Littoral Environnement et Sociétés (LIENSs), UMR 6250 CNRS-Université La Rochelle, 2 16 Rue Olympe de Gouges, 17042 La Rochelle Cedex 01, France

17
Correspondence to: Dr. Paco BUSTAMANTE

Littoral Environnement et Sociétés (LIENSs),

2 Rue Olympe de Gouges

F-17042 La Rochelle Cedex 01

France

Phone : +33 546507625

Fax : +33546458264

E-mail : pbustama@univ-lr.fr 
27 ABSTRACT: The concentrations of sixteen trace elements were investigated and compared 28 for the first time in the digestive and excreting tissues of two Nautilus species (Cephalopoda: Nautiloidea) from two geologically contrasted areas: 1) $N$. macromphalus from New Caledonia, a region characterised by its richness in nickel ores and its lack of tectonic activities and 2) N. pompilius from the Vanuatu archipelago showing high volcanic and tectonic activities. In both Nautilus species, results clearly highlighted that the digestive gland played a key role in the bioaccumulation and storage of $\mathrm{Ag}, \mathrm{Cd}, \mathrm{Ce}, \mathrm{Co}, \mathrm{Cu}, \mathrm{Fe}, \mathrm{La}, \mathrm{Nd}, \mathrm{V}$ and $\mathrm{Zn}$ whereas $\mathrm{As}, \mathrm{Cr}, \mathrm{Mn}, \mathrm{Ni}, \mathrm{Pb}$ and $\mathrm{Se}$ were accumulated in a greater extent in the excreting tissues (i.e. pericardial and renal appendages). Despite contrasting environments, no significant difference $(\mathrm{P}<0.05)$ was found between the two Nautilus species in the concentrations of most of the essential and non essential elements, including $\mathrm{Ni}$ and associated metals in $\mathrm{Ni}$ ores (i.e. Co and $\mathrm{Mn}$ ). As nautilus lives on the outer shelf of barrier reefs, these results strongly support the hypothesis that the New Caledonian lagoon traps the major amount of the trace elements derived from natural erosion and the intense mining activities conducted on land. In contrast, the concentrations of the rare earth elements $(\mathrm{Ce}, \mathrm{La}$, and $\mathrm{Nd}$ ) were significantly higher in $N$. pompilius than in $N$. macromphalus, probably as a result of the local enrichment of Vanuatu waters by specific environmental processes, such as

44 volcanism or upwelling.

Keywords: metals, metalloids, cephalopods, detoxification, excretion, South Pacific 


\section{INTRODUCTION}

Marine organisms are exposed to trace elements that are present in their diet and dissolved in seawater. This double exposure results in element accumulation in their different tissues whether or not these elements are essential to the metabolism (Rainbow, 2002). This process, widely described as bioaccumulation can vary greatly according to the specificities of the organisms such as age/size, sex and lifestyle, and according to the relative bioavailability of the metal in diet and seawater (Rainbow and Wang, 2001). Comparative analysis of trace element concentrations between closely related species living in different geographical areas can therefore allow at assessing the influence of the environment on their bioaccumulation. Among the marine species, cephalopods belong to a molluscan group comprising ca. seven hundred species (Boyle and Rodhouse, 2005), in which high concentrations of trace elements such as $\mathrm{Ag}, \mathrm{Cd}, \mathrm{Cu}$ or Zn have generally been recorded (Martin and Flegal, 1975; Finger and Smith, 1987; Miramand and Bentley, 1992; Yamada et al., 1997; Bustamante et al., 1998; Dorneles et al., 2007). Indeed, several studies have demonstrated that the digestive and the excretory organs of cephalopods play a major role in the bioaccumulation of trace elements, as these organs are deeply involved in the assimilation processes, detoxification and storage of both essential and non-essential metals (Miramand and Guary, 1980; Miramand and Bentley, 1992; Bustamante et al., 2000, 2002a,b, 2004).

In the present work, we focused on the bioaccumulation of trace elements in the Nautilus genus. Nautiluses are scavenger cephalopods, inhabiting the outer shelf of barrier reefs in the Indo-Pacific area, generally at a depth of 300 to 500 meters (O'Dor et al., 1993; Norman, 2000). In spite of its evolutionary interest (Nautilus is the last representative of ectocochleate cephalopods, i.e. considered as a "living fossil"; Boyle and Rodhouse, 2005) and its 
the pericardial appendages; Schipp et al., 1985; Westermann et al., 2002), only very few studies deal with the bioaccumulation of trace elements in this ancestral genus. High concentrations of several metals and metalloids were reported in the digestive and excretory tissues of Nautilus macromphalus (Bustamante et al., 2000), a species endemic to the New Caledonian waters. These authors suggested that the high metal concentrations may be due to a high exposure in the metal-rich conditions in the surrounding New Caledonian waters. Indeed, the largest resources of $\mathrm{Ni}$ as laterites in the world are present in New Caledonia where open-cast mining is conducted since the $20^{\text {th }}$ century, leading to a dramatic increase of metal concentrations in coastal waters and, subsequently, the metal burdens in marine biota (Labrosse et al., 2000; Metian et al., 2008). However, it is not clear whether metal accumulation observed in $N$. macromphalus reflected the impact of metal contamination through human activities on the outer shelf waters of New Caledonia or either if it is more due to a natural progressive bioaccumulation during nautilus long life span (viz. 10-15 years).

The aim of the present study was therefore to determine the bioaccumulation of a large range of elements in the genus Nautilus comparing two species from geologically contrasted areas: 1) N. macromphalus from New Caledonia which is characterised by its richness in nickel ores and its lack of tectonic activities and 2) N. pompilius from the Vanuatu archipelago which shows high volcanic and tectonic activities (Harrison et al, 1996). The analysed elements comprised 11 metals (Ag, Cd, Co, Cr, Cu, Fe, Mn, Ni, Pb, V and Zn), 2 metalloids (As and $\mathrm{Se})$ and 3 rare earth elements $(\mathrm{Ce}, \mathrm{La}$ and $\mathrm{Nd})$. These elements were selected for comparison with other species and other published works concerning Nautilus (e.g. Miramand et al. 1992, Bustamante et al. 2000, Ichihashi et al. 2001). The concentrations and relative contents of these different trace elements were determined in the digestive and the excretory tissues (i.e. pericardial and renal appendages) and compared between both nautilus species. The 
specificities and the potential influence of the environment on bioaccumulation of these trace elements in the Nautilus genus are discussed.

\section{MATERIALS AND METHODS}

\section{a) Biological material}

Three Nautilus pompilius and five Nautilus macromphalus specimens were collected respectively off Santo island coast (Vanuatu, 15 $40^{\prime} 522 \mathrm{~S}, 167^{\circ} 02^{\prime} 838 \mathrm{E}$, depth: $334 \mathrm{~m}$ ) and on the outer shelf of New-Caledonia (22 $20^{\prime} 500 \mathrm{~S}, 166^{\circ} 13^{\prime} 400 \mathrm{E}$, depth: 300m) in May 2006 (Figure 1). Each individual was measured and weighted prior to dissection. The main features of the eight specimens sampled are reported in Table 1.

All specimens were dissected aseptically and for each specimen one pericardial appendage, one renal appendage and a fraction of the digestive gland were immediately frozen in liquid nitrogen and stored at $-80^{\circ} \mathrm{C}$ for metal analyses.

\section{b) Analytical procedure}

Tissue samples were freeze-dried. Aliquots of the samples ranging from 20 to $300 \mathrm{mg}$ were digested using a 3:1 v:v nitric-hydrochloric acid mixture with $65 \%$ ultrapure $\mathrm{HNO}_{3}$ and ultrapure $70 \% \mathrm{HCl}$. The acidic digestion was performed overnight under ambient temperature and then heated in a microwave during 30 minutes, with increasing temperature until $105^{\circ} \mathrm{C}$, and 15 minutes at $105^{\circ} \mathrm{C}$ (1200 Watts). After the mineralization process, each sample was diluted to $30 \mathrm{ml}$ or $50 \mathrm{ml}$ with milli-Q quality water, according to the volume of acid added to the mineralization ( $3 \mathrm{ml}$ and $4.5 \mathrm{ml}$. respectively).

Ag, As, Cd, Ce, Co, Cr, Cu, Fe, La, Mn, Nd, Ni, Pb, Se, V and Zn were analysed either by ICP-OES (Varian ${ }^{\circledR}$ Vista-Pro) and ICP-MS (Varian ${ }^{\circledR}$ Ultra Mass 700). Reference tissues, dogfish liver DOLT-3 (NRCC), lobster hepatopancreas TORT-2 (NRCC) and Bush Branches 
and Leaves (GBW 07602) were treated and analysed in the same way as the samples. Results were in good agreement with the certified values, and the standard deviations were low, proving good repeatability of the method. The results for standard reference materials displayed recoveries of the elements ranging from $81 \%$ to $119 \%(n=10)$. For each set of analyses, blanks were included in each analytical batch. The detection limits $\left(\mu \mathrm{g} . \mathrm{g}^{-1}\right.$ dry wt) for ICP-OES were 8.3 (As, Fe, Zn), 3.3 (Ag, Se), 1.67 (Pb, V), 0.83 (Cd, Co, Cr, Cu, Mn, Ni), and for ICP-MS, they were $0.150(\mathrm{Ni}, \mathrm{V}), 0.065(\mathrm{Cd}, \mathrm{Co}, \mathrm{Cr}, \mathrm{Cu}, \mathrm{Mn}, \mathrm{Pb}), 0.033(\mathrm{Ag}), 0.017$ $(\mathrm{Nd}), 0.008$ (Ce, La). Average element concentrations are presented with standard deviations. All trace element concentrations are given on a dry weight basis $\left(\mu \mathrm{g} \cdot \mathrm{g}^{-1} \mathrm{dry} w \mathrm{w}\right)$.

\section{Data analyses}

Statistical analyses were performed using MINITAB 13.2 Software. Comparison of trace element concentrations in nautilus tissues between sites was tested by 1-way ANOVA. Hypothesis of normal distribution was tested using the Anderson-Darling test and equality of variance by the Bartlett test. Pearson coefficients were calculated between trace elements in each tissue. The significance level for statistical analyses was always set at $\alpha=0.05$.

\section{RESULTS}

\section{Trace element concentrations in the tissues}

Metal concentrations in the digestive gland, the renal appendages and the pericardial appendages of $N$. macromphalus and N. pompilius are reported in Table 2. La, Ce, and $\mathrm{Nd}$ concentrations fell below the detection limit in the renal appendages. Among the three tissues analysed, the digestive gland was the major site of accumulation for $\mathrm{Ag}, \mathrm{Cd}, \mathrm{Ce}, \mathrm{Co}, \mathrm{Cu}, \mathrm{Fe}$, La, Nd, V and $\mathrm{Zn}$ (Table 2). The digestive gland also concentrated $\mathrm{As}$ and $\mathrm{Ni}$ at 
147 concentrations close to the highest ones recorded in the other tissues. $\mathrm{As}, \mathrm{Cr}, \mathrm{Mn}, \mathrm{Ni}, \mathrm{Pb}$, and

148 Se concentrations were remarkable in excreting tissues. More specifically, the renal 149 appendages exhibited the highest $\mathrm{Mn}$ and $\mathrm{Se}$ concentrations, whereas $\mathrm{As}, \mathrm{Ni}$, and $\mathrm{Pb}$ were 150 concentrated at similar concentrations within both renal and pericardial appendages. Finally, 151 the pericardial appendages were the major site of accumulation for $\mathrm{Cr}$.

Comparison between species

154 Generally, the pattern of trace element concentrations was the same in both N. macromphalus and $N$. pompilius tissues. However, there were few exceptions and more particularly in the

156 digestive gland: firstly, $\mathrm{Ce}, \mathrm{Fe}, \mathrm{La}$, and $\mathrm{Nd}$ concentrations were significantly $(\mathrm{P}<0.05)$ higher 157 in N. pompilius; secondly, $\mathrm{Cd}$ and $\mathrm{Cr}$ concentrations were significantly $(\mathrm{P}<0.05)$ higher in $N$. 158 macromphalus (Table 3).

159 In the case of the pericardial appendages, As, La, and $\mathrm{Nd}$ concentrations were significantly 160 higher $(\mathrm{P}<0.05)$ in $N$. pompilius (Table 3). For the renal appendages, $\mathrm{Cu}$ was the only element 161 for which a significant difference was detected, $N$. pompilius having significantly higher 162 concentrations than N. macromphalus (Table 3).

Relative proportion of trace elements between tissues

165 Among the three tissues considered, the digestive gland contained the largest proportions of 166 most of the trace elements with 73 to $81 \%$ of $\mathrm{Ag}, 90$ to $91 \%$ of $\mathrm{Cd}, 61$ to $79 \%$ of $\mathrm{Ce}, 80$ to $16786 \%$ of $\mathrm{Co}, 67$ to $72 \%$ of $\mathrm{Cu}, 90$ to $93 \%$ of $\mathrm{Fe}, 72$ to $81 \%$ of $\mathrm{La}, 55$ to $75 \%$ of Nd, 56 to 67 of $168 \mathrm{~V}, 81 \%$ to $82 \%$ of $\mathrm{Zn}$ in both Nautilus species (Fig. 2). The only exception were As, Cr, Mn,

$169 \mathrm{Ni}, \mathrm{Se}$, and $\mathrm{Pb}$ which were mainly contained in the excreting tissues, i.e. renal and pericardial 170 appendages (Fig. 2). The renal appendages were the major site of accumulation of $\mathrm{Mn}, \mathrm{Ni}$, 171 and $\mathrm{Se}$ (i.e. 74 to $89 \%$ for $\mathrm{Mn}, 49$ to $54 \%$ for $\mathrm{Ni} ; 61$ to $73 \%$ for $\mathrm{Se}$ ) while the pericardial 
appendages accumulated the highest relative proportion of $\mathrm{Cr}$ (i.e. 63 to $74 \%$ ). Although the

173 concentrations of some of the trace elements were high in the excretory organs, these tissues contained in fact low amounts of metals because of their small masses.

175

\section{Correlations between metals}

177 Table 4 shows the correlation between trace elements within the three tissues. It is noteworthy

178 that the rare earth elements were correlated between each other within the digestive gland (r> 0.985 and $\mathrm{P}<0.001$ in all cases) and the pericardial appendages $(\mathrm{r}>0.922$ and $\mathrm{P}<0.003$ in all and $\mathrm{r}>0.807$ and $\mathrm{P}<0.004$ and $\mathrm{P}<0.028$, respectively) but negatively with $\mathrm{As}(\mathrm{r}>-0.726$ and $\mathrm{P}=0.047) . \mathrm{Cu}$ correlated positively with $\mathrm{Zn}(\mathrm{r}=0.834$ and $\mathrm{P}=0.020$ in all cases $)$ but negatively

183 with $\mathrm{Se}$ in this tissue ( $\mathrm{r}=-0.809$ and $\mathrm{P}=0.028$ in all cases).

184 In the renal appendages, correlations were weak, Mn varied positively with $\mathrm{Cd}(\mathrm{r}=0.833$, $\mathrm{P}=0.010)$ and $\mathrm{Zn}(\mathrm{r}=0.735, \mathrm{P}=0.038)$, Fe with $\mathrm{Zn}(\mathrm{r}=0.833, \mathrm{P}=0.010)$ and $\mathrm{Pb}$ with $\mathrm{Cr}$ ( $\mathrm{r}=0.936, \mathrm{P}=0.001)$ but negatively with $\mathrm{V}(\mathrm{r}=-0.753, \mathrm{P}=0.031$; Table 3$)$.

In the pericardial appendages, Cd concentrations correlated positively with $\mathrm{Cr}(\mathrm{r}=0.897$, $\mathrm{P}=0.006)$, $\mathrm{Ni}(\mathrm{r}=0.965, \mathrm{P}<0.001)$, and $\mathrm{V}(\mathrm{r}=0.931, \mathrm{P}=0.002)$.

\section{DISCUSSION}

192 The present extensive analysis of sixteen trace element concentrations in N. macromphalus

193 and $N$. pompilius digestive and excreting tissues clearly highlighted that these organs

194 constitute important tissues for the bioaccumulation of rare earth elements, metals and

195 metalloids. Such results support the hypothesis of efficient regulation processes for non 
essential metals in Nautilidae (Bustamante et al., 2000) even if, among the eight studied

197 specimens, the variability of metal concentrations was relatively high (Table 2).

198 In cephalopods, the digestive system plays a major role in both the digestive and the

199 detoxification processes: on the one hand, the digestive gland synthesizes the digestive 200 enzymes and is a place of absorption and assimilation of nutrients (Boucaud-Camou and 201 Boucher-Rodoni, 1983; Boucher-Rodoni and Boucaud-Camou, 1987); on the other hand, this organ is involved in the storage and detoxification of trace elements (Bustamante et al., $2002 \mathrm{ab}, 2004)$. Our investigations on trace element concentrations also confirmed the key role of the digestive gland of both $N$. macromphalus and $N$. pompilius in the metabolism of most of the analysed trace elements (i.e. $\mathrm{Ag}, \mathrm{Cd}, \mathrm{Ce}, \mathrm{Co}, \mathrm{Cu}, \mathrm{Fe}, \mathrm{La}, \mathrm{Nd}, \mathrm{V}$ and $\mathrm{Zn}$ ), as it is also the case in more recent cephalopods, i.e. belonging to the Coleoidae (e.g. Ghiretti-Magaldi et al., 1958; Martin and Flegal, 1975; Miramand and Guary, 1980; Smith et al., 1984; Finger and Smith, 1987; Miramand and Bentley, 1992; Seixas et al., 2005a; Pierce et al., 2008).

Our results also stressed the potential of excreting tissues (i.e. renal and pericardial appendages) to accumulate several elements such as $\mathrm{As}, \mathrm{Cr}, \mathrm{Mn}, \mathrm{Ni}, \mathrm{Pb}$, and $\mathrm{Se}$. In contrast to

211 the Coleoidae, in nautiluses the renal appendages are specialized in the storage of calcium and 212 the pericardial appendages play a major role in the evacuation of the metabolic wastes 213 (Schipp and Martin, 1987). These organs are known to harbour a dual bacterial symbiosis 214 (Pernice et al., 2007) involving spirochaetes and betaproteobacteria. The exact mechanisms 215 by which these bacterial symbionts are involved in nautilus excretion are still enigmatic. 216 Nevertheless, it is widely admitted that micro-organisms can play an important role in the 217 incorporation of trace elements (Worms et al., 2006). Accumulation of Co, Fe and Ni by 218 betaproteobacterial symbionts of the pericardial appendages of $N$. macromphalus has already 219 been observed by electronic microscopy (Pernice et al., in preparation). However, it remains 220 unclear if this accumulative process is only passive (viz. through adsorption processes) or 
active (viz. effective absorption of trace elements). Indeed, the betaproteobacterial symbionts

present in nautilus tissues could play a role in the detoxification and storage of some metals

such as $\mathrm{Co}, \mathrm{Fe}$ and $\mathrm{Ni}$ (Table 2). Such processes could involve enzymatic reduction and/or complexation with organic compounds (Pernice et al., 2006), leading to the storage of these metals at high concentrations in the excreting tissues, independently of the nautilus species. The role of this bacterial symbiosis on trace element bioaccumulation and detoxification in nautilus excreting tissues clearly deserves further investigations.

Although Nautilidae have been previously reported for their special abilities to accumulate heavy metals at relatively elevated concentrations in their tissues (Bustamante et al., 2000), this study is the first comparative approach aiming to compare trace element concentrations in 231 two Nautilus species from two geographically close areas (viz. distant from less than 1000

$232 \mathrm{kms}$ ). Both species potentially share common trophic features but, at the same time, they live 233 in geologically different environments (richness in nickel ores and lack of tectonic activities 234 in New Caledonia and high volcanic and tectonic activities in Vanuatu), potentially resulting 235 in a different degree of "natural" contamination. New Caledonia is currently the third largest 236 producer of $\mathrm{Ni}$ in the world (Dalvi et al., 2004) and mining activities associated to a strong natural erosion have resulted in the enrichment of $\mathrm{Ni}$ and associated metals in $\mathrm{Ni}$ ores (i.e. Co,

$238 \mathrm{Cr}, \mathrm{Cu}, \mathrm{Fe}$ and $\mathrm{Mn}$ ) and some other extracted metals (i.e. $\mathrm{Ag}$ and $\mathrm{Pb}$ ) in the coastal waters and 239 consequently in the lagoon food webs (Monniot et al., 1994; Fernandez et al., 2006; Hédouin 240 et al., 2006; Metian et al., 2008). Conversely, it is likely that the seawater concentrations of 241 most of these metals are very low in Santo islands waters and around Vanuatu in general 242 according to the absence of industrial and mining activities in this area (Harrison et al., 1996). 243 Surprisingly, in the present study, very little difference appeared in the sixteen trace element 244 concentrations between $N$. macromphalus from New Caledonia and N. pompilius from 245 Vanuatu. Interestingly, there was no significant difference between both Nautilus species for 
$\mathrm{Ag}, \mathrm{Co}, \mathrm{Mn}, \mathrm{Ni}, \mathrm{Pb}, \mathrm{Se}, \mathrm{V}$ and $\mathrm{Zn}$ (Table 3) indicating that the geographical origin does not

247 seem to be a major factor contributing to interspecific variations of these trace element 248 concentrations. As nautilus lives on the outer shelf of barrier reefs and rarely penetrates into 249 lagoons (Saunders and Ward, 1987; Norman, 2000), our results strongly supported the 250 hypothesis that the New Caledonian lagoon traps the major amount of the trace elements 251 derived from the island (Ambatsian et al., 1997). To the best of our knowledge, there are no 252 published data in the open literature concerning trace elements in organisms from the oceanic 253 waters off New Caledonia, except for two marine mammal species (Bustamante et al., 2003). These authors reported very low concentrations of $\mathrm{Co}, \mathrm{Cr}$ and $\mathrm{Ni}$ in the marine mammal tissues which suggested that mining activity in New Caledonia does not seem to be a 256 significant source of contamination in the oceanic domain. Overall, the global geologic 257 contagion due to the mining activity in New Caledonia seems to be limited to the shoreline 258 waters and to the inner lagoon (Fernandez et al., 2006).

259 More interestingly, the concentrations of rare earth elements were significantly different 260 between the digestive gland and the pericardial appendages of $N$. macromphalus and $N$. 261 pompilius. F-transition elements of rare earths have similar physicochemical properties, and it 262 is therefore not surprising that they correlate to each other (Table 4). Our results suggested 263 that rare earth elements would reflect the characteristics of the surrounding environment. 264 Very little is known about the concentrations of Ce, La and $\mathrm{Nd}$ in cephalopods, which varied 265 from 0.045 to $1.95 \mu \mathrm{g} \cdot \mathrm{g}^{-1} \mathrm{dwt}$ in the digestive gland of the squid Stenoteuthis oualaniensis 266 (Ichihashi et al., 2001). In fact, rare earth elements have chemistry and sorption/complexation 267 characteristics analogous to transuranic elements such as americium or plutonium (Choppin 268 Torres and Chopin, 1984; Kim et al., 1989; Buckau et al., 1992). In Coleoid cephalopods, 269 transuranic elements also accumulate in the digestive and excreting tissues, in particular in the 270 branchial heart and their appendages (Guary et al., 1981; Guary and Fowler, 1982; 
271 Bustamante et al., 2006). It is therefore not surprising that they accumulate at relatively high

272 concentrations in nautilus digestive gland and pericardial appendage.

273 Besides $\mathrm{Ce}, \mathrm{La}$ and $\mathrm{Nd}$, the concentrations of $\mathrm{As}, \mathrm{Cu}$ and $\mathrm{Fe}$ were also higher in N. pompilius

274 than in N. macromphalus. It is difficult to ascertain the reasons of such a difference but this

275 might also be linked to geological features reflecting a potential enrichment of Vanuatu

276 waters by local environmental processes, such as volcanism or upwelling (Malinovsky and

277 Markevich, 2007). In fact, only two trace elements, $\mathrm{Cd}$ and Cr, displayed significantly higher

278 concentrations in $N$. macromphalus than in $N$. pompilius tissues (Table 2). Therefore, the

279 reasons of such interspecific differences in bioaccumulation, i.e. higher concentrations of

280 trace elements in one species, remain unclear whereas an absence of difference could be

281 explained by the similar physiology of these two species (Ward, 1988; Norman, 2000).

282 As for other marine organisms, in cephalopods, trace element concentrations may vary with

283 biological and environmental factors such as temperature, salinity, season, age (size), sex,

284 lifestyle and geographical origin (e.g. Monteiro et al., 1992; Bustamante et al., 1998;

285 Raimundo et al., 2004; Seixas et al., 2005b; Pierce et al., 2008). Further investigations are

286 needed to understand how exactly these factors affect their concentrations in the studied

287 species. However, among these factors, individual size/age is known to be of primary

288 importance in invertebrates (e.g. Warnau et al., 1995; Bustamante and Miramand, 2005;

289 Hédouin et al., 2007). In the present study, the size as well as the two others main features

290 measured (sex and weight) were globally homogenous among the eight studied specimens.

291 Because nautiluses are long lived animals, it would be striking to determine the influence of

292 the size/age on trace elements bioaccumulation.

293 Sources of trace elements to nautilus can be (1) seawater, as it passes through the skin and

294 through the gills during respiration, and (2) food, which is now considered as a major route

295 for metal accumulation in marine animals, including both invertebrates and fish (Koyama et 
al., 2000; Wang, 2002; Bustamante et al., 2002a, 2004). Knowledge of trace element

297 speciation in the direct environment of nautilus is a key factor to ascertain the relative 298 importance of each uptake pathways. Concerning the first pathway (i.e. seawater), further 299 aquatic toxicity studies are needed to determine the fraction of total metal dissolved in 300 seawater (the 'toxic fraction') that react with, and is transported across biological membranes 301 such as nautilus gills. Concerning the second pathway (i.e. food), our comparative analysis suggested that the metal discharges due to intense mining activities conducted on land in New 303 Caledonia are not easily transferred in the food web of nautilus. Therefore, to assess the impact of mining activities on cephalopods in the region of New Caledonia, further studies should be conducted on more coastal species known to be resident in the impacted areas, such as Sepiidae, Sepiolidae or Octopodidae spending all of their life in the waters of the New

307 Caledonian lagoon.

\section{ACKNOWLEDGMENTS}

311 We thank the Aquarium and the centre IRD of Nouméa (New Caledonia) as well as the

312 Maritime college of Luganville (Vanuatu) for their help in providing Nautilus macromphalus and N. pompilius specimens, respectively. This work was supported by the Muséum National

314 d'Histoire Naturelle (pluriformations programme: "Ecologie fonctionnelle et développement 315 durable des écosystèmes naturels et anthropisés"), the University Pierre-et-Marie Curie, the 316 CNRS (UMR 5178 and UMR 6250 LIENSs) and a research grant from the Government of 317 New Caledonia awarded by the Pacific Fund.

\section{REFERENCES}


Ambatsian, P., Fernex, F., Bernat, M., Parron, C., Lecolle, J. 1997. High metal inputs to 322 closed seas: the New Caledonian lagoon. J. Geochem. Explor. 59, 59-74.

Boucaud-Camou, E., Boucher-Rodoni, R. 1983. Feeding and digestion in Cephalopods. In: 325 The Mollusca, Part 2, physiology (Wilbur, K M ed). Academic press, New York, 1983, pp. $326 \quad 149-180$.

Boucher-Rodoni, R., Boucaud-Camou, E. 1987. Fine structure and absorption of ferritin in the $173-184$.

Boyle, P., Rodhouse, P. 2005. Cephalopods: Ecology and Fisheries Blackwell publishing, Ames. 452 pp.

335 Buckeau, G., Kim, J.I., Klenze, R., Rhee, D.S., Wimmer, H. 1992. A comparative study of the 336 fulvate complexation of trivalent transuranic ions. Radiochim. Acta 57, 105-112.

338 Bustamante, P., Cherel, Y., Caurant, F., Miramand, P. 1998. Cadmium, copper and zinc in 339 octopuses from Kerguelen Islands, southern Indian Ocean. Polar Biol. 19, 264-271.

341 Bustamante, P., Grigioni, S., Boucher-Rodoni, R., Caurant, F., Miramand, P. 2000. 342 Bioaccumulation of 12 trace elements in the tissues of the nautilus Nautilus macromphalus 343 from New Caledonia. Mar. Pollut. Bull. 40, 688-696. 
345 Bustamante, P., Cosson, R.P., Gallien, I., Caurant, F., Miramand, P. 2002a. Cadmium 346 detoxification processes in the digestive gland of cephalopods in relation to accumulated 347 cadmium concentrations. Mar. Environ. Res. 53, 227-241.

349 Bustamante, P., Teyssié, J-L., Fowler, S.W., Cotret, O., Danis, B., Miramand, P., Warnau, M. 350 2002b. Biokinetics of zinc and cadmium accumulation and depuration at different stages in 351 the life cycle of the cuttlefish Sepia officinalis. Mar. Ecol. Prog. Ser. 231, 167-177.

353 Bustamante, P., Garrigue, C., Breau, L., Caurant, F., Dabin, W., Greaves, J., Dodemont, R. 354 2003. Trace elements in two odontocetes species (Kogia breviceps and Globicephala macrorhynchus) stranded in New Caledonia (South Pacific). Environ. Pollut. 124, 263-271.

Bustamante, P., Teyssié, J-L., Danis, B., Fowler, S.W., Miramand, P., Cotret, O., Miramand, P., Warnau, M. 2004. Uptake, transfer and distribution of silver and cobalt in tissues of the common cuttlefish Sepia officinalis at different stages of its life cycle. Mar. Ecol. Prog. Ser. 269, 185-195.

Bustamante, P., Miramand, P. 2005. Evaluation of the variegated scallop Chlamys varia as a biomonitor of temporal trends of $\mathrm{Cd}, \mathrm{Cu}$, and $\mathrm{Zn}$ in the field. Environ. Pollut. 138, 109-120.

Bustamante, P., Teyssié, J-L., Fowler, S.W., Warnau, M. 2006. Assessment of the exposure 366 pathway in the uptake and distribution of americium and cesium in cuttlefish (Sepia officinalis) at different stages of its life cycle. J. Exp. Mar. Biol. Ecol. 331, 198-207.

369 Choppin Torres, R.A., Choppin, G.R. 1984. Europium (III) and americium (III) stability constants with humic acid. Radiochim. Acta 34, 143-148. 
372 Dalvi, A.D., Bacon, W.G., Osborne, R.C. 2004. The past and the future of nickel laterites. 373 PDAC International Convention, Trade Show and Investors Exchange. March 7-10, 27 pp.

374

375 Dorneles, P.R., Lailson-Brito, J., Aguiar dos Santos, R., Silva da Costa, P.A., Malm, O., 376 Freitas Azevedo, A., Machado Torres, J.P. 2007. Cephalopods and cetaceans as indicators of 377 offshore bioavailability of cadmium off Central South Brazil Bight. Environ. Pollut. 148, 352378359.

380 Eisler, R. 1981. Trace metals concentration in marine organisms. Pergamon Press, New York, $381685 \mathrm{pp}$.

382

383 Fernandez, J.M., Ouillon, S., Chevillon, C., Douillet, P., Fichez, R., Legendre, R. 2006. A 384 combined modelling and geochemical study of the fate of terrigenous inputs from mixed 385 natural and mining sources in a coral reef lagoon (New Caledonia) Mar. Pollut. Bull. 52, 320386331.

388 Finger, J.M., Smith, J.D. 1987. Molecular association of $\mathrm{Cu}, \mathrm{Zn}, \mathrm{Cd}$ and ${ }^{210} \mathrm{Po}$ in the digestive 389 gland of the squid Nototodarus gouldi. Mar. Biol. 95, 87-91.

391 Ghiretti-Magaldi, A., Giuditta, A., Ghiretti, F. 1958. Pathways of terminal respiration in 392 marine invertebrates. I. The respiratory system in cephalopods. J. Cell. Comp. Physiol. 52, 393 $389-429$. 
395 Guary, J-C., Higgo, J.J.W., Cherry, R.D., Heyraud, M. 1981. High concentrations of 396 transuranic and natural radioactive elements in the branchial hearts of the cephalopods Octopus vulgaris. Mar. Ecol. Prog. Ser. 4, 123-126.

Guary, J-C., Fowler, S.W. 1982. Experimental studies on the biokinetics of plutonium and americium in the cephalopod Octopus vulgaris. Mar. Ecol. Prog. Ser. 7, 327-335.

401

Harrison, N., Gangaiya, P., Morrison, R.J. 1996. Organochlorines in the Coastal Marine

404

Hédouin, L., Metian, M., Teyssié, J-L., Fowler, S.W., Fichez, R., Warnau, M. 2006.

Allometric relationships in the bioconcentration of heavy metals by the edible tropical clam

Gafrarium tumidum. Sci. Total Environ. 366, 154-163.

408

Hédouin, L., Pringault, O., Metian, M., Bustamante, P., Warnau, M. 2007. Nickel bioaccumulation in bivalves from the New Caledonia lagoon: Seawater and food exposure. Chemosphere 66, 1449-1457.

Hirano, S., Suzuki, K.T. 1996. Exposure, metabolism, and toxicity of rare earth and related compounds. Environ. Health Perspect. 104, 85-95.

415

Kim, J.I., Buckeau, G., Bryant, E., Klenze, R. 1989. Complexation of americium (III) with

Koyama, J., Nanamori, N., Segawa, S. 2000. Bioaccumulation of waterborne and dietary 
423

424

425

426

427

430

431

432

433

434

435

436

437

438

439 Metian, M., Bustamante, P., Hédouin, L., Warnau, M. 2008. Accumulation of trace elements

440 in the tropical scallop Comptopallium radula from coral reefs in New Caledonia. Environ.

441 Pollut. 152: 543-552.

442

443 Miramand, P., Guary, J-C. 1980. High concentrations of some heavy metals in tissues of the 444 Mediterranean octopus. Bull. Environ. Contam. Toxicol. 24, 783-788. 
446 Miramand, P., Bentley, D. 1992. Concentration and distribution of heavy metals in tissues of 447 two cephalopods, Eledone cirrhosa and Sepia officinalis, from the French coast of the English 448 Channel. Mar. Biol. 114, 407-414.

449

450 Monniot, F., Martoja, R., Monniot, C. 1994. Cellular sites of iron and nickel accumulation in 451 ascidians related to the naturally and anthropic enriched New Caledonian environment. 452 Annal. Inst. Océanogr. 70, 205-216.

453

454 Monteiro, L.R., Porteiro, F.M., Gonçalves, J.M. 1992. Inter- and intra-specific variation of 455 mercury levels in muscle of cephalopods from the Azores. Arquipelago 10, 13-22.

456

457 O’Dor, R.K., Forsythe, J., Webber, D.M., Wells, J., Wells, M.J. 1993. Activity levels of 458 Nautilus in the wild. Nature 362, 626-627.

459

460 Pernice, M., Wetzel, S., Gros, O., Boucher-Rodoni, R., Dubilier, N. 2007. Enigmatic dual 461 symbiosis in the excretory organs of Nautilus macromphalus (Cephalopoda: Nautiloidea). 462 Proc. Royal Soc. Lond. Ser. Biol. Sci. 274, 1143-1152.

463

464 Pernice, M., Boucher, J., Joannot, P., Boucher-Rodoni, R. 2006. Comparative study of 465 bacteria diversity and bioaccumulation of trace elements in the excretory organs of Nautilus. 466 In: CIAC symposium 2006, February 6-10, Hobart, Australia, 120 pp.

468 Pierce, G.J., Stowasser, G., Hastie, L.C., Bustamante, P. 2008. Geographic, seasonal and 469 ontogenetic variation in cadmium and mercury concentrations in squid (Cephalopoda: 
470 Teuthoidea) from UK waters. Ecotox. Environ. Safety in press 471 (doi:10.1016/j.ecoenv.2007.07.007).

472

473 Rainbow, P.S., Wang, W-X. 2001. Comparative assimilation of Cr, Cr, Se, and Zn by the 474 barnacle Elminius modestus from phytoplankton and zooplankton diets. Mar. Ecol. Prog. Ser. $475218,239-248$.

476

477 Rainbow, P.S. 2002. Trace metal concentrations in aquatic invertebrates: why and so what? 478 Environ. Pollut. 120, 497-507.

479

480 Raimundo, J., Caetano, M., Vale, C. 2004. Geographical variation and partition of metals in 481 tissues of Octopus vulgaris along the Portuguese coast. Sci. Total Environ. 325, 71-81.

482

483 Saunders, W., Ward, P.D. 1987. Ecology, distribution and population characteristics of 484 Nautilus. In: Nautilus, the biology and paleobiology of a living fossil Saunders, WB \& 485 Landman, NH. (eds). New-York \& London, Plenum press, 137-162 pp.

486

487 Schipp, R., Martin, A.W., Liebermann, H., Magnier, Y. 1985. Cytomorphology and function 488 of pericardial appendages of Nautilus (Cephalopoda, Tetrabranchiata). Zoomorph. 105, 16-29. 489

490 Schipp, R., Martin, A.W. 1987. The excretory system of Nautilus. In: Nautilus, the biology 491 and Paleobiology of a living fossil (WB Sauders and NH. Landman, eds). Plenum Press, New 492 York, 281-304 pp. 
494 Seixas, S., Bustamante, P., Pierce, G.J. 2005a. Interannual patterns of variation in 495 concentrations of trace elements in arms of Octopus vulgaris. Chemosphere 59, 1113-1124.

496

497 Seixas, S., Bustamante, P., Pierce, G.J. 2005b. Accumulation of mercury in the tissues of the 498 common octopus Octopus vulgaris (L.) in two localities on the Portuguese coast. Sci. Total 499 Environ. 340, 113-122.

500

501 Smith, J.D., Plues, L., Heyraud, M., Cherry, R.D. 1984. Concentrations of the elements Ag, $\mathrm{Al}, \mathrm{Ca}, \mathrm{Cd}, \mathrm{Cu}, \mathrm{Fe}, \mathrm{Mg}, \mathrm{Pb}$ and $\mathrm{Zn}$, and the radionuclides ${ }^{210} \mathrm{~Pb}$ and ${ }^{210} \mathrm{Po}$ in the digestive 503 gland of the squid Nototodarus gouldi. Mar. Environ. Res. 13, 55-68.

504

505

Wang, W-X. 2002. Cd and Se aqueous uptake and exposure of green mussels Perna viridis: influences of seston quantity. Mar. Ecol. Prog. Ser. 226, 211-221.

507

508

Ward, P.D. 1988. In search of Nautilus “A New York Academy of Sciences book”, Simon \& 509 Schuster eds, New-York.

Warnau, M., Ledent, G., Temara, A. 1995. Allometry of heavy metal bioconcentration in the echinoid Paracentrotus lividus. Arch. Environ. Contam. Toxicol. 29, 393-399.

513

514 Westermann, B., Ruth, P., Litzbauer, H.D., Beck, I., Beuerlin, K., Schimdtberg, H., Kleta, 515 E.F., Schipp, R. 2002. The digestive tract of Nautilus pompilius (Cephalopoda, 516 Tetrabranchiata): an X-ray analytical and computational tomography study on the living 517 animal. J. Exp. Biol. 205, 1617-1624. 
519 Worms, I., Simona, D.F., Hasslera, C.S., Wilkinson, K.J. 2006. Bioavailability of trace metals

520 to aquatic microorganisms: importance of chemical, biological and physical processes on 521 biouptake. Biochimie 88, 1721-1731.

522

523 Yamada, H., Takayanagi, K., Tateishi, M., Tagata, H., Ikeda, K. 1997. Organotin compounds 524 and polychlorinated biphenyls of livers in squid collected from coastal waters and open ocean. 525 Environ. Pollut. 96(2), 217-226. 
526 Table 1. Characteristics of the sampled specimens of Nautilus pompilius and $N$. 527 macromphalus.

528

\begin{tabular}{cccc}
\hline Species & Sex & Length (mm) & Weight (g) \\
\hline N. pompilius & & & \\
1 & Male & 177 & 825 \\
2 & Male & 151 & 660 \\
3 & Male & 171 & 796 \\
N. macromphalus & & & \\
1 & Male & 164 & 766 \\
2 & Female & 162 & 676 \\
3 & Male & 173 & 870 \\
4 & Male & 160 & 758 \\
5 & Male & 140 & 480 \\
\hline
\end{tabular}


529 Table 2: Trace elements concentrations (Mean $\pm \mathrm{SE} ; \mu \mathrm{g} \mathrm{g}^{-1}$ dry wt) in the tissues of Nautiloidae from this study and from the literature. The

530 highest values are in bold. dl: detection limit; NA: not analysed; \# only one value.

\begin{tabular}{|c|c|c|c|c|c|c|c|c|c|c|c|c|c|c|c|c|}
\hline \multirow[b]{2}{*}{ Tissue } & \multicolumn{3}{|c|}{ Rare earth elements } & \multicolumn{3}{|c|}{ Non essential metals } & \multicolumn{10}{|c|}{ Essential metals and metalloids } \\
\hline & $\mathrm{La}$ & $\mathrm{Ce}$ & $\mathrm{Nd}$ & $\mathrm{Ag}$ & $\mathrm{Cd}$ & $\mathrm{Pb}$ & As & Co & $\mathrm{Cr}$ & $\mathrm{Cu}$ & $\mathrm{Fe}$ & $\mathrm{Mn}$ & $\mathrm{Ni}$ & $\mathrm{Se}$ & $\mathrm{V}$ & $\mathrm{Zn}$ \\
\hline \multicolumn{17}{|c|}{ Nautilus macromphalus_(Bustamante et al. 2000) } \\
\hline Digestive gland & NA & NA & NA & $4.45 \pm 2.68$ & $45.1 \pm 13.2$ & $0.46 \pm 0.17$ & $166 \pm 26$ & $7.8 \pm 3.6$ & $4.4 \pm 1.1$ & $106 \pm 46$ & $666 \pm 231$ & $10.1 \pm 1.7$ & $16.3 \pm 7.8$ & NA & $8.8 \pm 2.0$ & $672 \pm 208$ \\
\hline Pericardial appendages & NA & NA & NA & $20.3 \pm 6.2$ & $2.16 \pm 1.63$ & $1.00 \pm 0.82$ & $260 \pm 111$ & $1.31 \pm 0.80$ & $8.25 \pm 1.55$ & $27.2 \pm 33.4$ & $78 \pm 46$ & $25.1 \pm 23.0$ & $5.64 \pm 3.54$ & NA & $0.18 \pm 0.09$ & $22.4 \pm 26.6$ \\
\hline Renal appendages & NA & NA & NA & $1.80 \pm 2.22$ & $1.87 \pm 1.23$ & $1.06 \pm 0.88$ & $112 \pm 65$ & $0.43 \pm 0.37$ & $2.54 \pm 2.88$ & $7.1 \pm 10.2$ & $343 \pm 160$ & $77.1 \pm 54.1$ & $22.7 \pm 13.9$ & NA & $1.02 \pm 0.72$ & $11.0 \pm 16.8$ \\
\hline \multicolumn{17}{|c|}{ N. macromphalus (Present study) } \\
\hline Digestive gland & $0.30 \pm 0.07$ & $0.25 \pm 0.11$ & $0.19 \pm 0.07$ & $9.42 \pm 3.91$ & $51.5 \pm 3.5$ & $0.98 \pm 0.15$ & $257 \pm 19$ & $4.69 \pm 1.51$ & $2.95 \pm 0.35$ & $263 \pm 78$ & $353 \pm 63$ & $10.9 \pm 1.3$ & $14.0 \pm 1.04$ & $2.65 \pm 0.90$ & $14.8 \pm 2.28$ & $388 \pm 61$ \\
\hline Pericardial appendages & $0.11 \pm 0.02$ & $0.17 \pm 0.05$ & $0.15 \pm 0.05$ & $1.82 \pm 0.54$ & $1.93 \pm 0.76$ & $1.57 \pm 0.11$ & $169 \pm 19$ & $0.65 \pm 0.09$ & $9.59 \pm 3.35$ & $73.7 \pm 9.9$ & $19 \pm 1$ & $12.7 \pm 2.9$ & $6.93 \pm 1.37$ & $3.72 \#$ & $5.62 \pm 2.26$ & $56.5 \pm 1.8$ \\
\hline Renal appendages & $<\mathrm{dl}$ & $<\mathrm{dl}$ & $<\mathrm{dl}$ & $0.44 \pm 0.12$ & $3.39 \pm 1.16$ & $2.11 \pm 0.51$ & $152 \pm 17$ & $0.18 \pm 0.03$ & $2.57 \pm 0.36$ & $27.6 \pm 4.2$ & $20 \pm 3$ & $68.2 \pm 6.2$ & $19.7 \pm 2.39$ & $9.84 \pm 0.94$ & $1.54 \pm 0.13$ & $35.2 \pm 2.8$ \\
\hline \multicolumn{17}{|c|}{ N. pompilius (Present study) } \\
\hline Digestive gland & $1.00 \pm 0.14$ & $1.58 \pm 0.32$ & $0.92 \pm 0.10$ & $5.65 \pm 1.04$ & $74.3 \pm 6.8$ & $0.62 \pm 0.07$ & $210 \pm 16$ & $3.85 \pm 1.04$ & $1.37 \pm 0.24$ & $311 \pm 61$ & $625 \pm 51$ & $15.4 \pm 1.7$ & $9.77 \pm 0.07$ & $2.35 \pm 0.84$ & $8.42 \pm 0.57$ & $470 \pm 52$ \\
\hline Pericardial appendages & $0.24 \pm 0.03$ & $0.42 \pm 0.05$ & $0.31 \pm 0.01$ & $1.75 \pm 0.07$ & $2.39 \pm 0.37$ & $1.24 \pm 0.24$ & $323 \pm 53$ & $0.79 \pm 0.07$ & $9.30 \pm 3.87$ & $99.7 \pm 2.4$ & $21 \pm 3$ & $24.1 \pm 4.9$ & $7.02 \pm 0.79$ & $2.49 \#$ & $4.94 \pm 0.74$ & $58.2 \pm 2.7$ \\
\hline Renal appendages & $<\mathrm{dl}$ & $<\mathrm{dl}$ & $<\mathrm{dl}$ & $0.35 \pm 0.03$ & $5.93 \pm 0.31$ & $0.99 \pm 0.21$ & $292 \pm 80$ & $0.18 \pm 0.03$ & $1.98 \pm 0.08$ & $53.3 \pm 4.6$ & $24 \pm 3$ & $307 \pm 83$ & $19.6 \pm 0.97$ & $13.3 \pm 6.12$ & $1.82 \pm 0.02$ & $42.7 \pm 1.5$ \\
\hline
\end{tabular}


$533(\mathrm{~Np})$ and in N. macromphalus (Nm). NS: not significant.

534

\begin{tabular}{|c|c|c|c|}
\hline Element & Digestive gland & Pericardial appendages & Renal appendages \\
\hline \multicolumn{4}{|c|}{ Rare earth elements } \\
\hline $\mathrm{Ce}$ & $\begin{array}{c}\mathrm{Np}>\mathrm{Nm} \\
(\mathrm{F}=19.58 ; \mathrm{p}=0.007)\end{array}$ & NS & - \\
\hline $\mathrm{La}$ & $\begin{array}{c}\mathrm{Np}>\mathrm{Nm} \\
(\mathrm{F}=23.40 ; \mathrm{p}=0.005)\end{array}$ & $\begin{array}{c}\mathrm{Np}>\mathrm{Nm} \\
(\mathrm{F}=0.609 ; \mathrm{p}=0.025)\end{array}$ & - \\
\hline $\mathrm{Nd}$ & $\begin{array}{c}\mathrm{Np}>\mathrm{Nm} \\
(\mathrm{F}=25.13 ; \mathrm{p}=0.004)\end{array}$ & $\begin{array}{c}\mathrm{Np}>\mathrm{Nm} \\
(\mathrm{F}=6.54 ; \mathrm{p}=0.051)\end{array}$ & - \\
\hline \multicolumn{4}{|c|}{ Essential elements } \\
\hline As & NS & $\begin{array}{c}\mathrm{Np}>\mathrm{Nm} \\
(\mathrm{F}=9.58 ; \mathrm{p}=0.027)\end{array}$ & NS \\
\hline Co & NS & NS & NS \\
\hline $\mathrm{Cr}$ & $\begin{array}{c}\mathrm{Nm}>\mathrm{Np} \\
(\mathrm{F}=11.34 ; \mathrm{p}=0.020)\end{array}$ & NS & NS \\
\hline $\mathrm{Cu}$ & NS & NS & $\begin{array}{c}\mathrm{Np}>\mathrm{Nm} \\
(\mathrm{F}=15.58 ; \mathrm{p}=0.008)\end{array}$ \\
\hline $\mathrm{Fe}$ & $\begin{array}{c}\mathrm{Np}>\mathrm{Nm} \\
(\mathrm{F}=10.09 ; \mathrm{p}=0.025)\end{array}$ & NS & NS \\
\hline $\mathrm{Mn}$ & NS & NS & NS \\
\hline $\mathrm{Ni}$ & NS & NS & NS \\
\hline $\mathrm{Se}$ & NS & NS & NS \\
\hline $\mathrm{V}$ & NS & NS & NS \\
\hline $\mathrm{Zn}$ & NS & NS & NS \\
\hline \multicolumn{4}{|c|}{ Non essential elements } \\
\hline $\mathrm{Ag}$ & NS & NS & NS \\
\hline $\mathrm{Cd}$ & $\begin{array}{c}\mathrm{Nm}>\mathrm{Np} \\
(\mathrm{F}=0.740 ; \mathrm{p}=0.023)\end{array}$ & NS & NS \\
\hline $\mathrm{Pb}$ & NS & NS & NS \\
\hline
\end{tabular}


535 Table 4: Correlations between trace elements within the different tissues of nautilus.

536 Not underlined: $\mathrm{p}<0.05$; underlined: $\mathrm{p}<0.001$.

\begin{tabular}{|c|c|c|c|}
\hline Elements & Digestive gland & Renal appendages & $\begin{array}{l}\text { Pericardial } \\
\text { appendages }\end{array}$ \\
\hline $\mathrm{La}$ & $\pm \mathrm{Ce}, \underline{+\mathrm{Nd}},-\mathrm{As}, \pm \mathrm{Fe},+\mathrm{Mn}$ & $<\mathrm{dl}$ & $+\mathrm{Ce},+\mathrm{Nd},+\mathrm{Mn}$ \\
\hline $\mathrm{Ce}$ & $\pm \mathrm{Nd}, \underline{-\mathrm{As}},+\mathrm{Fe},+\mathrm{Mn}$ & $<\mathrm{dl}$ & $\underline{+\mathrm{Nd}}, \underline{+\mathrm{Co}}, \underline{\mathrm{La}}$ \\
\hline $\mathrm{Nd}$ & $+\mathrm{Fe},+\mathrm{Mn}$ & $<\mathrm{dl}$ & $\overline{+\mathrm{Ce}}, \overline{+\mathrm{Co}},+\overline{\mathrm{La}}$ \\
\hline $\mathrm{Cu}$ & $+\mathrm{Zn},-\mathrm{Se}$ & - & - \\
\hline $\mathrm{Fe}$ & $+\mathrm{Mn},-\mathrm{V},+\underline{\mathrm{La}}, \underline{+\mathrm{Ce}}, \underline{\mathrm{Nd}}$ & $+\mathrm{Zn}$ & $+\mathrm{Ag},+\mathrm{Mn},+\mathrm{Cr}$ \\
\hline $\mathrm{Pb}$ & $+\mathrm{V}$ & $-\mathrm{V}, \underline{+\mathrm{Cr}}$ & - \\
\hline Mn & $+\mathrm{La},+\mathrm{Ce},+\mathrm{Nd},+\mathrm{Fe}$ & $+\mathrm{Cd},+\mathrm{Zn}$ & $+\mathrm{La}, \underline{+\mathrm{Fe}}$ \\
\hline $\mathrm{Cd}$ & - & $\underline{+\mathrm{Mn}}$ & $+\mathrm{Ni},+\mathrm{V},+\mathrm{Cr}$ \\
\hline
\end{tabular}

538

$539<\mathrm{dl}$ : concentrations below the detection limit. 
542 Figure 1: Location of Nautilus pompilius and N. macromphalus specimens' collection.

543

544 Figure 2: Relative distribution of the trace elements between the digestive gland (DG),

545 pericardial appendages (PA) and renal appendages (RA) of Nautilus pompilius from Vanuatu

546 (black) and N. macromphalus from New Caledonia (white). Scale bars represent 1 standard 547 error.

548

549

550

551

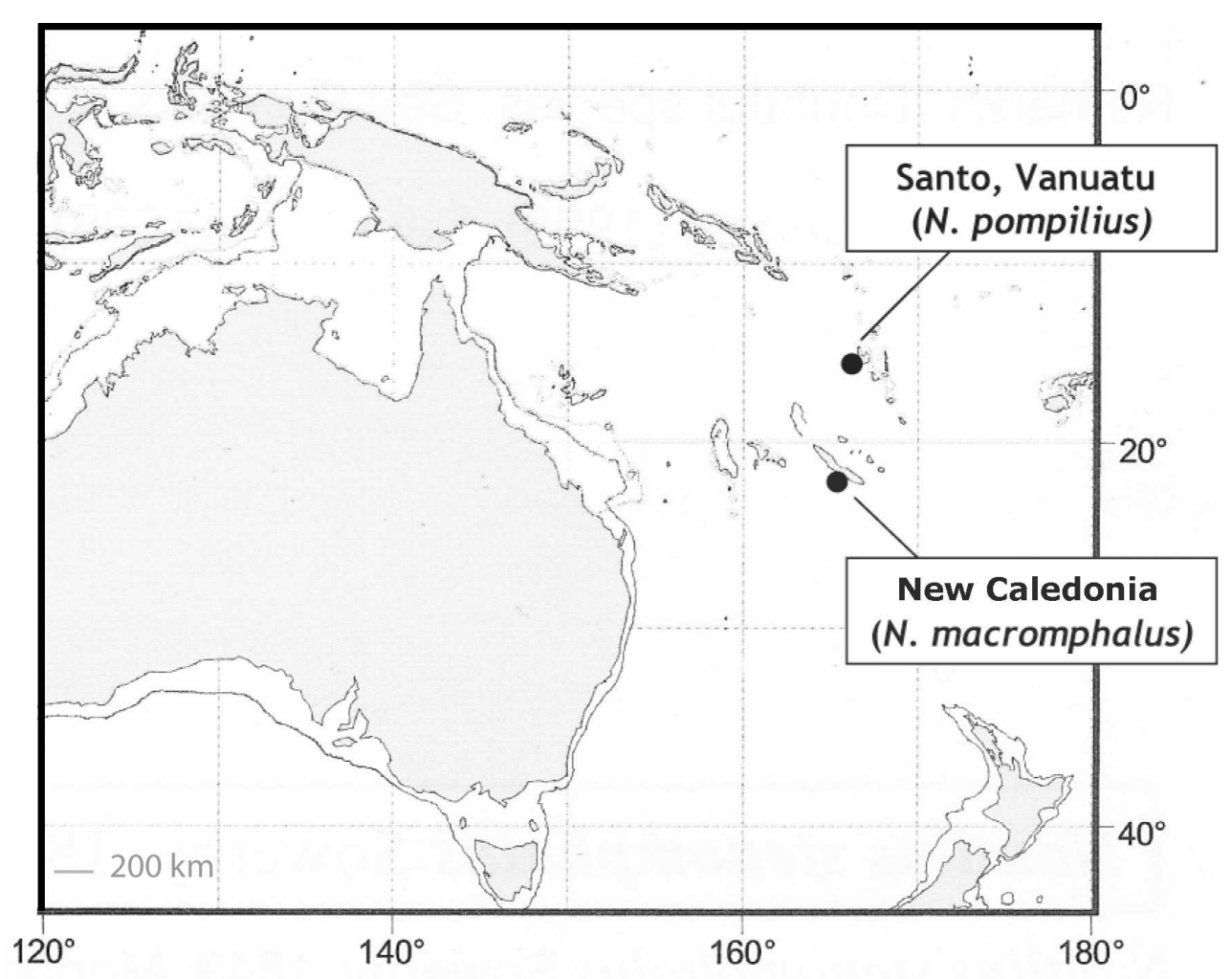

Figure 1. 


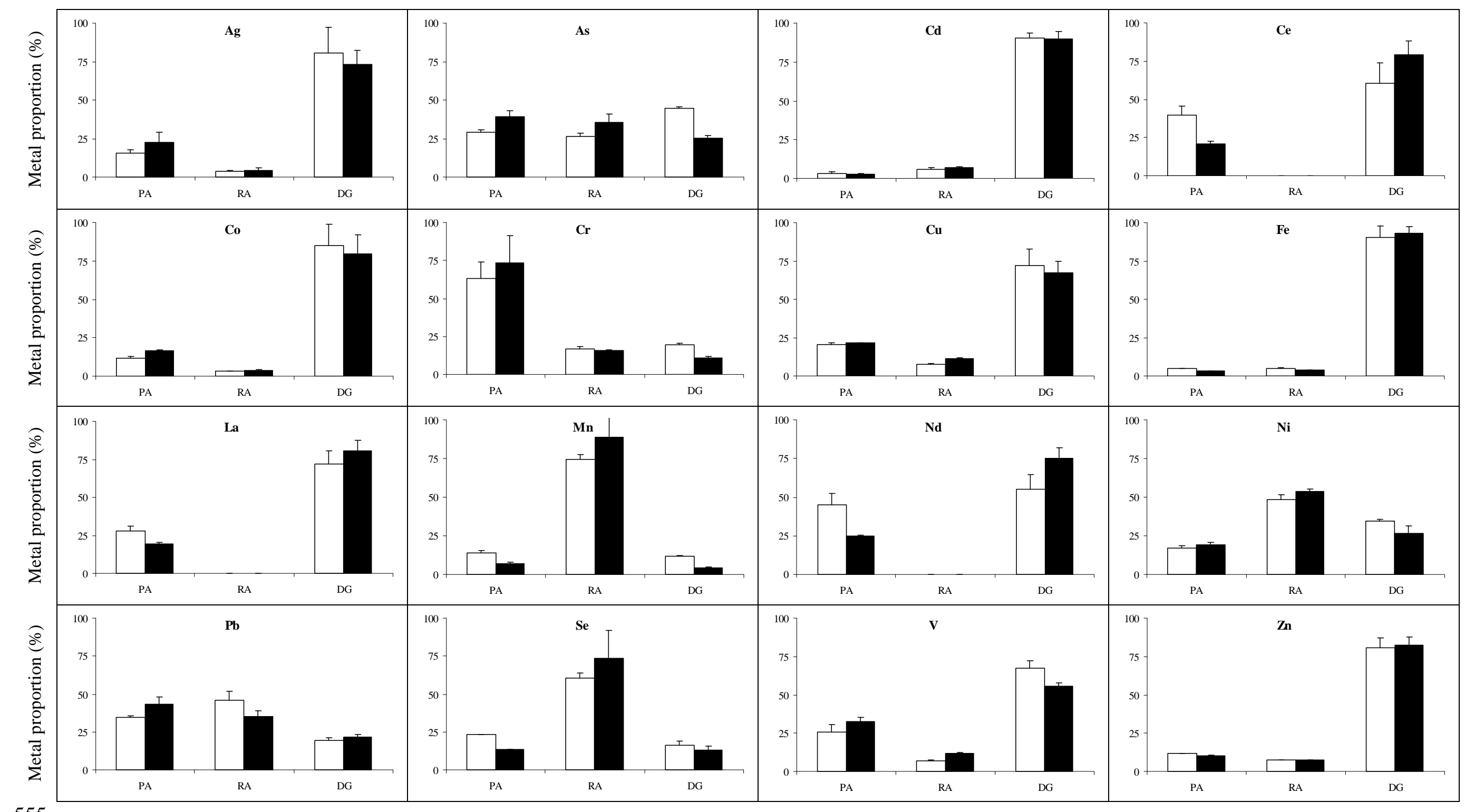

